\title{
EXTREME ALTERATIONS OF PERMEABILITY WITHOUT INJURY
}

(WITH FOUR FIGURES)

W. J. V. OSTERHOUT

It has been pointed out in a previous paper ${ }^{x}$ that in the opinion of some writers permeability is a relatively fixed property of the cell, and that it is altered only as the result of injury; the alteration is then irreversible. Others assume ${ }^{2}$ that there are reversible changes in permeability which may form a normal part of the activities of the cell. In view of the fact that such changes may control metabolism, it seemed important to establish the truth or falsity of this assumption by rigorous proof.

This was successfully accomplished by the use of quantitative methods. The previous paper contained a brief statement of some of the results obtained; the present paper adds important data and describes subsequent experiments in which an extreme range of permeability was attained and very rapid changes were investigated.

The permeability was measured by determining the electrical resistance of living tissues of Laminaria saccharina by a method which has been previously described. ${ }^{3}$

It has been shown that the electrical resistance of the living tissue falls rapidly where it is transferred from sea water to a solution of $\mathrm{NaCl}$ of the same conductivity, and that within certain limits this effect is reversible. Tissue which in sea water had a resistance of $1020 \mathrm{ohms}^{4}$ was placed in a solution of $\mathrm{NaCl} 0.5^{2} \mathrm{M}$ which had the same conductivity as the sea water. In the course of five minutes the resistance fell to $830 \mathrm{ohms}$. The tissue was replaced in sea water; the resistance soon rose to normal and so continued during the remainder of the day.

${ }^{x}$ Science N.S. $36: 350$. 1912.

${ }^{2}$ Cf. Höвer, Physikalische Chemie der Zelle und Gewebe. Kap. 7 und 1o. I9II.

${ }^{3}$ Science N.S. 35: II 2. I9I2.

${ }^{4}$ All readings were taken at $18^{\circ} \mathrm{C}$. unless otherwise stated. 
As the electrical conductivity of the tissue is a measure of the permeability of the protoplasm to ions, we may calculate the percentage of increase of permeability by finding the change in conductivity. In the present instance it is more convenient to use the change in conductance without reducing this to specific conductivity. The resistance at the start was 1020 ohms, but this includes the resistance of the apparatus with its contained sea water. Evidently this should be subtracted from the total resistance; the remainder will be called the net resistance. ${ }^{5}$

In this case the resistance of the apparatus was $250 \mathrm{ohms}$. The net resistance of the tissue at the start, therefore, was $1020-25^{\circ}=$ $770 \mathrm{ohms}$; the net conductance was $\mathrm{x} \div 770=0.00130$ mho. At the end of five minutes in $\mathrm{NaCl}$ the net resistance was $830-250=$ $580 \mathrm{ohms}$; the net conductance was $\mathrm{I} \div 580=0.00 \mathrm{I} 72 \mathrm{mho}$. The increase in permeability, therefore, amounts to $0.00172-0.00130=$ 0.00042 mho, or 32.3 per cent. $^{6}$

It might be objected that this increase in conductance was not due to an increase in permeability but to an increase in the ions of sodium chloride, to which the tissue might be assumed to be normally more permeable than to some of the other ions of the sea water. This, however, cannot be the case, as is shown by the following experiment. Tissue having a resistance of $1020 \mathrm{ohms}$ was placed in a mixture of $1000 \mathrm{cc} . \mathrm{NaCl} 0.5^{2} \mathrm{M}+20$ cc. $\mathrm{CaCl}_{2}$ $0.278 \mathrm{M}$. The resistance remained at $1020 \mathrm{ohms}$ in this mixture. The tissue was then transferred to $\mathrm{NaCl} 0.5_{2}^{2} \mathrm{M}$ for five minutes. At the end of this time the resistance had fallen to $860 \mathrm{ohms}$; on being placed in sea water the resistance rose to the normal and so remained for some time.

In this case the resistance of the apparatus was $230 \mathrm{ohms}$. The net resistance at the start was $1020-230=790 \mathrm{ohms}$; and the net

${ }^{5}$ In the previous paper it was suggested that the tissue should be killed, that the resistance of the apparatus should be measured while the dead tissue remained in it, and that this should be subtracted from the total; the remainder was called the net resistance. It seems better, however, to take the resistance of the apparatus after the tissue has been removed, to subtract this from the total, and call the remainder the net resistance.

${ }^{6}$ Complete recovery after such a large increase of permeability is not always obtainable unless the material is in good condition and is freshly collected. Even in such material a lot will occasionally be found which shows poor recovery. 
conductance $\mathrm{I} \div 790=0.00 \mathrm{I} 27$ mho. After treatment with $\mathrm{NaCl}$ the net resistance was $860-230=630 \mathrm{ohms}$, and the net conductance was $1 \div 630=0.00159$ mho. The increase in net conductance, therefore, was $0.00159-0.00127=0.00032 \mathrm{mho}$, or 25.2 per cent. The increase in the percentage of sodium ions was only 2 per cent, while the content of chlorine ions remained unchanged. It is evident, therefore, that there was a great increase in permeability.

In order to see whether this increase of permeability is accompanied by injury, an experiment was made in which the same piece of tissue was exposed to the action of $\mathrm{NaCl}$ several times during the same day. The resistance of the tissue in sea water was roro ohms; after five minutes in $\mathrm{NaCl}$ the resistance fell to $880 \mathrm{ohms}$; the tissue was then placed in sea water and a reading ten minutes later showed that the resistance had risen to roro ohms. During the next 95 minutes it showed no change. It was then placed in $\mathrm{NaCl}$ for five minutes and the resistance fell to $870 \mathrm{ohms}$. It was replaced in sea water; a reading taken ten minutes later showed that it had returned to normal, where it remained for 90 minutes without change. It was then placed in $\mathrm{NaCl}$ for five minutes. The resistance fell to $900 \mathrm{ohms}$ and returned to normal during the ensuing ten minutes in sea water. After 105 minutes in sea water, during which no change occurred, it was again exposed to $\mathrm{NaCl}$ for five minutes. The resistance fell to $870 \mathrm{ohms}$ and returned again to normal during the following ten minutes in sea water. On the following day its resistance was only $30 \mathrm{ohms}$ below the resistance of the control, which at the beginning of the experiment was 1040 ohms. The results are presented graphically in fig. I.

The successful outcome of this experiment lead to an attempt to carry on such an experiment for several days in succession, giving the tissue one treatment daily with $\mathrm{NaCl}$. The material was selected with especial care. The fronds were fairly thick, without reproductive organs. The experiment was made at Woods Hole, Mass., in July, at which time such fronds may be easily obtained. The disks cut from these fronds were slightly curved, so that when placed in the apparatus they separated spontaneously, thus allowing the running sea water in which they were kept to 
circulate freely between them. Care was taken to keep them only about two-thirds submerged, so that they had free access to air without any risk of drying.

The tissue had in sea water a resistance of $1020 \mathrm{ohms}$ at $20^{\circ} \mathrm{C}$. As the temperature of the sea water varied but slightly from this during the experiment, all readings were taken at $20^{\circ} \mathrm{C}$. On being placed in $\mathrm{NaCl} 0.5_{2} \mathrm{M}$ at this temperature, the resistance fell in five minutes to $890 \mathrm{ohms}$; it was then placed in sea water and a reading taken ten minutes later showed that it had risen again to the normal. The resistance of the apparatus was $240 \mathrm{ohms}$; hence

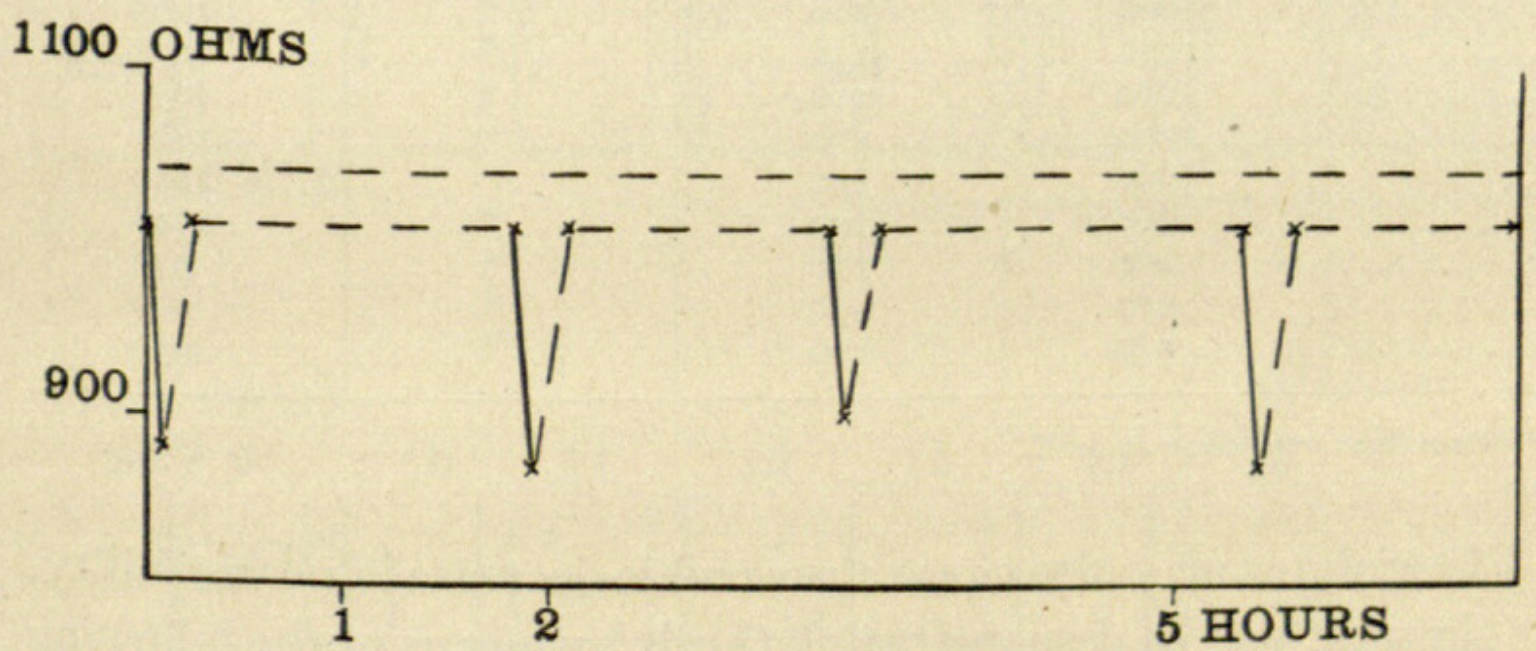

FIG. I.-Alterations of permeability shown by curves of the electrical resistance of Laminaria saccharina in $\mathrm{NaCl} 0.52 \mathrm{M}$ (unbroken line) and in sea water (dotted portion of the curve); the horizontal dotted line (above) shows the resistance of the control.

the net resistance at the start was $1020-240=780 \mathrm{ohms}$, and the net conductance $\mathrm{I} \div 780=0.00 \mathrm{I} 28 \mathrm{mho}$. The net resistance after treatment with $\mathrm{NaCl}$ was $890-240=650 \mathrm{ohms}$, and the net conductance $\mathrm{I} \div 650=0.00 \mathrm{I}_{54}$ mho. The increase in permeability, therefore, was $0.00154-0.00128=0.00026 \mathrm{mho}$, or 20.3 per cent.

The tissue was then placed in running sea water for 22 hours, with the precautions mentioned above. At the end of 22 hours the resistance was $1020 \mathrm{ohms}$ at $20^{\circ} \mathrm{C}$. An exposure of five minutes to $\mathrm{NaCl}$ resulted in a drop to $920 \mathrm{ohms}$, with complete recovery within ten minutes. The same treatment was given once each day for $I_{5}$ days. On the tenth day the resistance began to fall off, but as this falling off was also shown by the control, which remained in 
'sea water through the experiment, it was not due to the sodium chloride but to other causes. The results are shown in table I and fig. 2 .

TABLE I*

\begin{tabular}{|c|c|c|c|c|}
\hline Day & $\begin{array}{l}\text { Resistance before } \\
\text { exposure }\end{array}$ & $\begin{array}{l}\text { Fall of resistance } \\
\text { after } 5 \mathrm{minutes} \\
\text { in } \mathrm{NaCl}\end{array}$ & Recovery & Control in sea water \\
\hline $1 \ldots \ldots \ldots$ & 1020 & 130 & Complete & 1030 \\
\hline $2 \ldots \ldots \ldots \ldots$ & 1020 & 100 & " & 1030 \\
\hline $3 \ldots \ldots \ldots$ & 1020 & I IO & " & 1030 \\
\hline $4 \ldots \ldots \ldots$ & 1020 & 140 & " & 1030 \\
\hline $5 \ldots \ldots \ldots \ldots$ & 1020 & I 20 & " & 1030 \\
\hline $6 \ldots \ldots \ldots$ & 1020 & I 20 & " & 1030 \\
\hline $7 \ldots \ldots \ldots$ & 1020 & 100 & " & 1030 \\
\hline $8 \ldots \ldots \ldots$ & 1020 & I30 & " & 1030 \\
\hline $9 \ldots \ldots \ldots$ & 1020 & 120 & " & 1030 \\
\hline Io.......... & - 1000 & 120 & " & 1020 \\
\hline II $\ldots \ldots \ldots$ & 1000 & IIO & " & IOIO \\
\hline $12 \ldots \ldots \ldots$ & 980 & 100 & " & IOIO \\
\hline $13 \ldots \ldots \ldots$ & 960 & IIO & $"$ & 970 \\
\hline I $4 \ldots \ldots \ldots \ldots$ & $95^{\circ}$ & 120 & $"$ & 960 \\
\hline I $5 \ldots \ldots \ldots \ldots$ & 930 & 100 & & $95^{\circ}$ \\
\hline
\end{tabular}

* All readings were taken at $20^{\circ} \mathrm{C}$.

Electrolytes may also cause a reversible decrease in permeability. The simplest way of demonstrating this is by means of the following very striking experiment. The resistance of a cylinder of living tissue in sea water was found to be $750 \mathrm{ohms}$. It was tested an hour later and found to be the same. Sufficient lanthanum nitrate ( $8.7 \mathrm{gm}$. to rooo cc. sea water) was then added in solid form to make its concentration ${ }^{7}$ in the sea water o. or M. After five minutes the resistance rose to $900 \mathrm{ohms}$. As the resistance of the apparatus was $250 \mathrm{ohms}$, the net resistance before the addition of lanthanum was $750-250=500 \mathrm{ohms}$, and the net conductance $I \div 500=0.002$ mho. After treatment with lanthanum nitrate, the net resistance was $900-250=650 \mathrm{ohms}$, and net conductance $\mathrm{I} \div 650=0.00 \mathrm{I} 54 \mathrm{mho}$, a loss of 23 per cent.

7 The concentration was reduced by the precipitation of a small amount of lanthanum sulphate; this had practically no influence on the subsequent result, since the outcome is the same if we use in place of sea water a mixture of $1000 \mathrm{cc} . \mathrm{NaCl} 0.5_{2} \mathrm{M}+$ $20 \mathrm{cc} . \mathrm{CaCl}_{2} \circ .278 \mathrm{M}$, in which case no precipitate is formed. It should be noted that the addition of lanthanum chloride has the same effect as the addition of lanthanum nitrate. 
In order to ascertain whether this change in permeability is reversible, the tissue was replaced in sea water. In the course of an hour its resistance returned again to the original condition. ${ }^{8}$ The experiment was then repeated three times on the same lot of material with practically the same result; it was then allowed to stand over night in sea water. On the following day there was no

\section{OHMS}

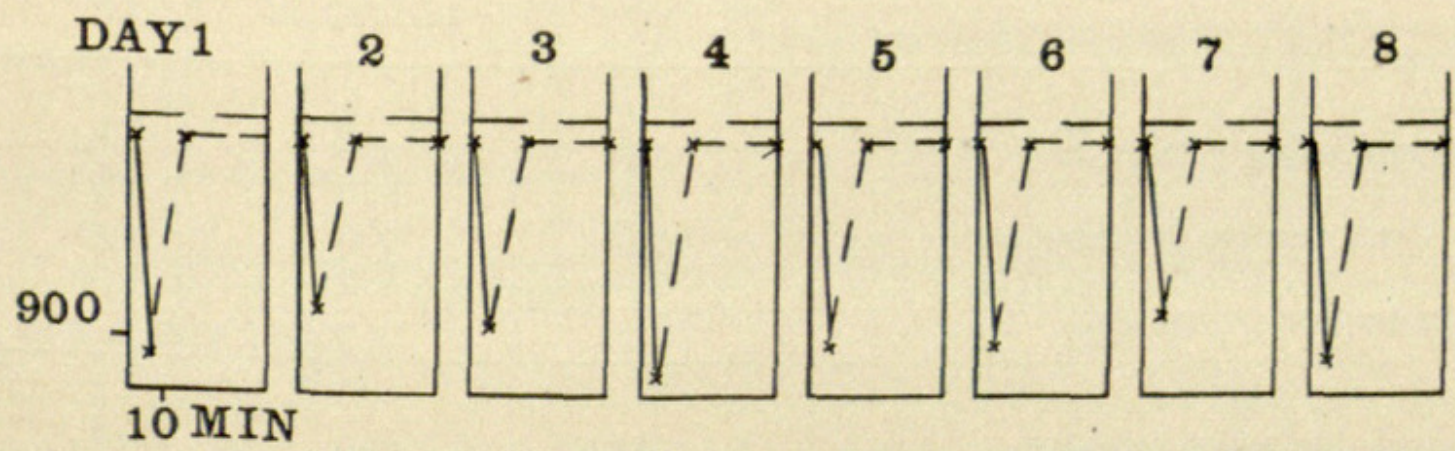

\section{0 . OHMS}

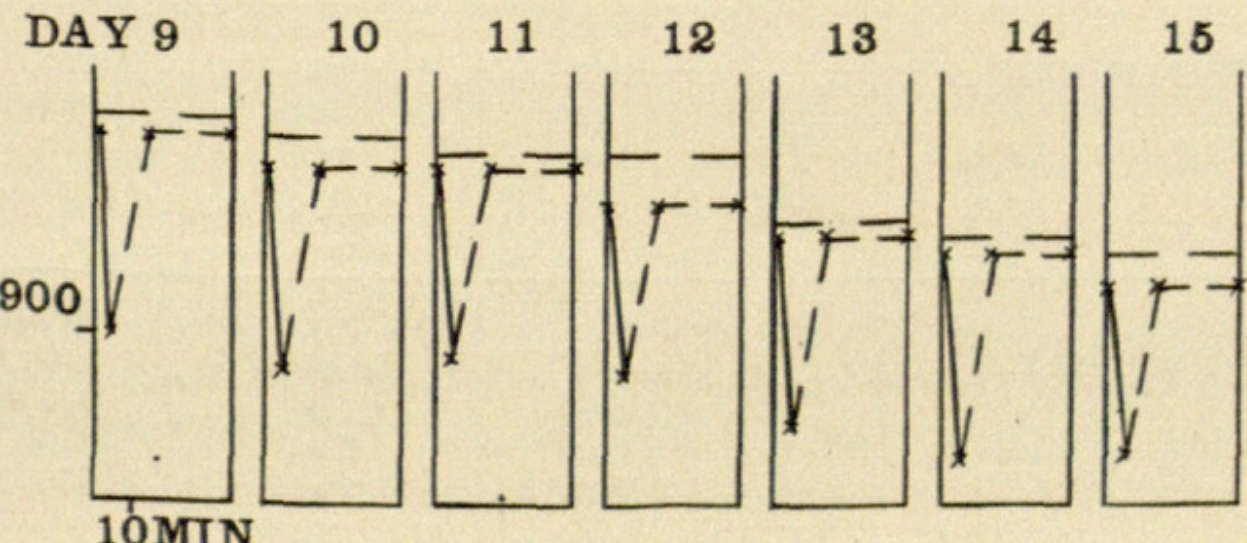

FIG. 2.-Alterations of permeability shown by curves of the electrical resistance of Laminaria saccharina in $\mathrm{NaCl} 0.5_{2} \mathrm{M}$ (unbroken line) and in sea water (dotted portion of curve); upper dotted line, control in sea water.

appearance of injury, and its resistance was the same as that of the control, which had remained in sea water throughout the experiment. The tissue was then placed in the sea water plus lanthanum and left until its resistance had increased roo ohms; it was then put back into sea water and left until the resistance fell to nearly normal. This was repeated three times, and the tissue

${ }^{8}$ If the material is left in sea water plus lanthanum nitrate the increased resistance is maintained for a long time unaltered. 
was then allowed to stand over night in sea water. On the third, fourth, and fifth days the same experiment was repeated four times. On the fifth day the tissue appeared to be in as good condition as the control, and had a resistance which was slightly higher. There

TABLE II*

\begin{tabular}{|c|c|c|c|}
\hline & $\begin{array}{c}\text { Resistance at } \\
\text { start of exposure }\end{array}$ & $\begin{array}{c}\text { Resistance rose } \\
\text { in sea water } \\
+\mathrm{La}_{2}\left(\mathrm{NO}_{3}\right)_{6} \text { to }\end{array}$ & Recovered to \\
\hline $\begin{array}{l}\text { Day I- } \\
\text { Exposed during } 5 \text { minutes } \\
\text { Recovered during } 55 \text { minutes } \\
\text { Control }=730\end{array}$ & $\begin{array}{l}75^{\circ} \\
75^{\circ} \\
75^{\circ} \\
75^{\circ}\end{array}$ & $\begin{array}{l}900 \\
870 \\
900 \\
850\end{array}$ & $\begin{array}{l}75^{\circ} \\
750 \\
75^{\circ} \\
75^{\circ}\end{array}$ \\
\hline $\begin{array}{l}\text { Day } 2- \\
\text { Exposed during } 20 \text { minutes } \\
\text { Recovered during } 100 \text { minutes } \\
\text { Control }=690\end{array}$ & $\begin{array}{l}700 \\
710 \\
710 \\
710\end{array}$ & $\begin{array}{l}860 \\
830 \\
850 \\
840\end{array}$ & $\begin{array}{l}710 \\
710 \\
710 \\
710\end{array}$ \\
\hline $\begin{array}{l}\text { Day } 3- \\
\text { Exposed during } 30 \text { minutes } \\
\text { Recovered during } \text { roo minutes } \\
\text { Control }=660\end{array}$ & $\begin{array}{l}690 \\
710 \\
720 \\
710\end{array}$ & $\begin{array}{l}790 \\
800 \\
790 \\
790\end{array}$ & $\begin{array}{l}710 \\
720 \\
710 \\
700\end{array}$ \\
\hline $\begin{array}{l}\text { Day } 4- \\
\text { Exposed during } 30 \text { minutes } \\
\text { Recovered during } 100 \text { minutes } \\
\text { Control }=650\end{array}$ & $\begin{array}{l}670 \\
680 \\
670 \\
680\end{array}$ & $\begin{array}{l}760 \\
750 \\
780 \\
770\end{array}$ & $\begin{array}{l}680 \\
670 \\
680 \\
680\end{array}$ \\
\hline $\begin{array}{l}\text { Day } 5 \text { - } \\
\text { Exposed during } 40 \text { minutes } \\
\text { Recovered during } \text { I } 20 \text { minutes } \\
\text { Control }=6_{5} \circ\end{array}$ & $\begin{array}{l}660 \\
660 \\
660 \\
660\end{array}$ & $\begin{array}{l}760 \\
780 \\
770 \\
760\end{array}$ & $\begin{array}{l}660 \\
660 \\
660 \\
660\end{array}$ \\
\hline
\end{tabular}

*All readings were taken at $20^{\circ} \mathrm{C}$.

was no reason, therefore, to suspect that the changes in permeability had been attended by any injurious effect. The results are shown in detail in table II and fig. 3 .

Similar experiments were performed in which calcium chloride was used in place of lanthanum nitrate. In this case $3.3 \mathrm{gm}$. 
$\mathrm{CaCl}_{2}$ were added to each rooo cc. of sea water. Owing to the fact that the rise in resistance took place more slowly ${ }^{9}$ than when lanthanum was used, the experiment was performed twice on each of the five successive days. On the sixth day the material was in as good condition as the control and had the same resistance.
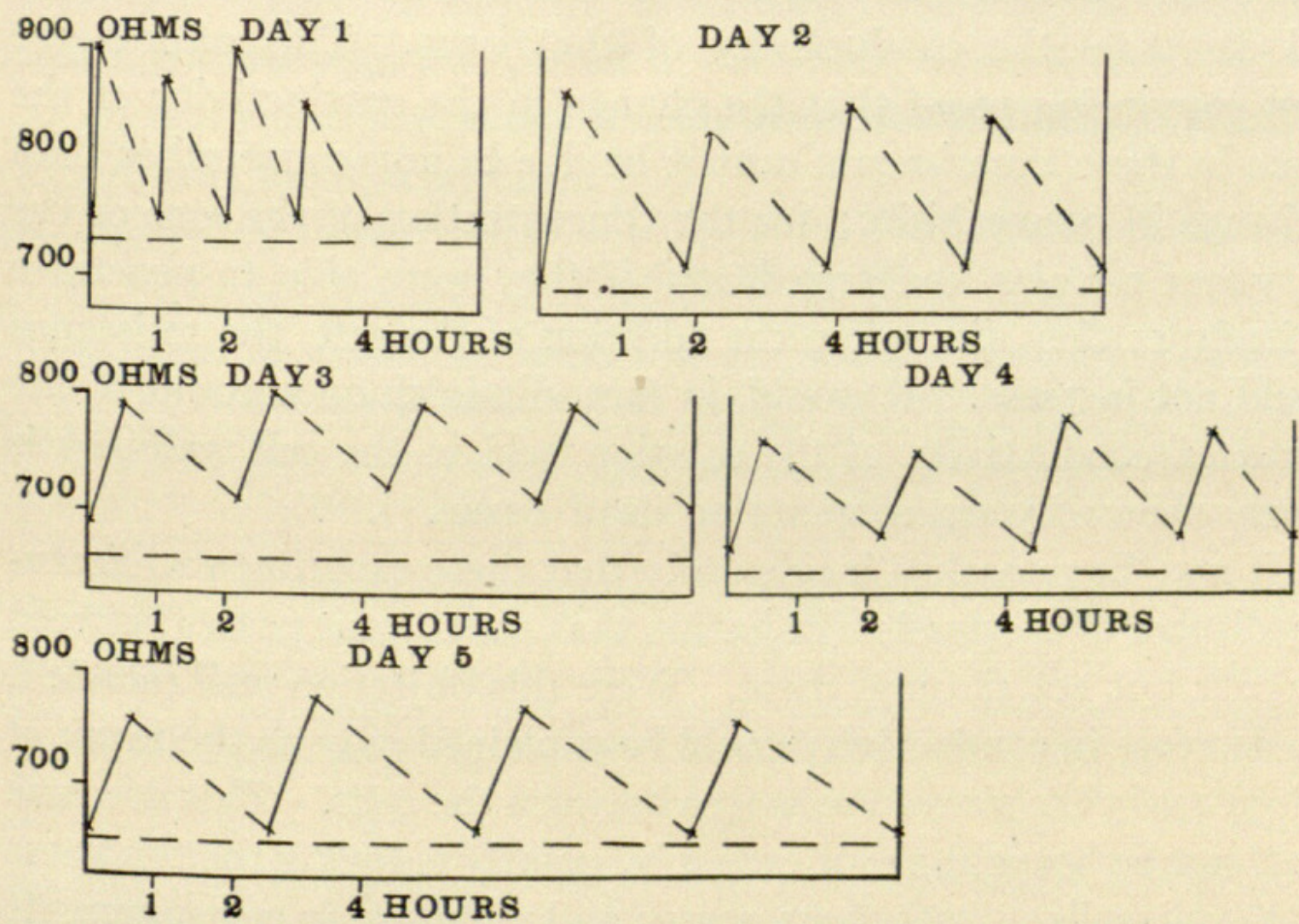

FIG. 3.-Alterations of permeability shown by curves of the electrical resistance of Laminaria saccharina in sea water, and in 1000 cc. sea water+2.6 gms. $\mathrm{La}_{3}\left(\mathrm{NO}_{3}\right)_{6}$ $(=0$. or $\mathrm{M})$; the same lot of material was exposed four times daily on five successive days to the action of $1000 \mathrm{cc}$. sea water $+\mathrm{La}_{2}\left(\mathrm{NO}_{3}\right)_{6}$; unbroken part of curve, resistance in sea water $+\mathrm{La}_{2}\left(\mathrm{NO}_{3}\right)_{6}$; dotted part of curve, resistance in sea water; lower horizontal dotted line, control in sea water.

It is evident, therefore, that the permeability may be greatly decreased and then restored to the normal several times on five successive days without any trace of injury. Further experiments showed that the permeability may be alternately increased and decreased twice daily for five days without injury. The amount of increase and of decrease was about the same as in the experiments just described.

9 If in place of solid $\mathrm{CaCl}_{2}$ a strong solution is added, the rise is more rapid and reaches a higher figure. 
Experiments on dead tissue (killed by heat or by formalin or allowed to die a natural death) showed that the results described above are due entirely to the living cells.

A very marked decrease of permeability may be produced by a considerable variety of other salts. The addition of these salts in solid form simultaneously increases the conductivity of the solution and decreases the conductivity of the tissue. This affords the most convincing proof that the change in the conductivity of the tissue in these experiments cannot be due to any cause other than a change in permeability; for the concentration of the ions of the sea water remains unchanged, and if they were able to penetrate as freely as they did before the addition of the salt, the resistance would not increase. It would, in fact, diminish on account of the increased conductivity of the solution held in the cell walls, as is clearly shown by experiments on dead tissue.

It may be remarked incidentally that these experiments effectually dispose of the possible objection that the current passes between the cells but not through them. Were this objection well founded, the decrease in conductivity could be explained only as the result of a decrease in the size of the spaces between the cells. This decrease could not be brought about except by greatly reducing the thickness of the cell walls. Both macroscopic and microscopic measurements show most conclusively that this does not occur. The contrary effect would be produced by the addition of salts in solid form, for they would tend to produce plasmolysis and thereby to increase the space between the cells.

As these remarkable changes in permeability seemed to produce no bad effects, it occurred to the writer to see whether the protoplasm could endure still more violent alterations without permanent injury. In order to test this the following experiment was performed. A lot of tissue was found to have in sea water a resistance of Ioro ohms. It was placed in $\mathrm{CaCl}_{2} \circ .278 \mathrm{M}$, which had the same conductivity as the sea water. At the end of ten minutes a reading was taken which showed that the resistance had risen to ${ }_{1} 500 \mathrm{ohms}$. The material was then placed in $\mathrm{NaCl} 0.5_{2}^{2} \mathrm{M}$, which had the same conductivity as the sea water; at the end of ten minutes the resistance was $880 \mathrm{ohms}$. The experiment was con- 
tinued by placing the material for ten minutes alternately in $\mathrm{CaCl}_{2}$ and $\mathrm{NaCl}$, with the results shown in table III and fig. 4. After 80 minutes the material was placed in sea water, where it soon regained its normal resistance of roro ohms. Twenty hours later the resistance was found to be unaltered and the experiment was repeated. After 80 minutes of alternate exposure to $\mathrm{CaCl}_{2}$ and $\mathrm{NaCl}$, the material was placed in sea water, where it soon regained its normal resistance, which it maintained for three days, when the experiment was discontinued.

TABLE III*

Alterations IN ELECTRICAL RESISTANCE OF Laminaria saccharina EXPOSED FOR IO MINUTES ALternately to $\mathrm{CaCl}_{2} 0.278$ AND $\mathrm{NaCl} 0.5_{2} \mathrm{M}$

\begin{tabular}{|c|c|c|c|c|c|}
\hline \multicolumn{3}{|c|}{ DAY I } & \multicolumn{3}{|c|}{ DAY 2} \\
\hline $\begin{array}{l}\text { Time in } \\
\text { minutes }\end{array}$ & Solution & Resistance & $\begin{array}{l}\text { Time in } \\
\text { minutes }\end{array}$ & Solution & Resistance \\
\hline 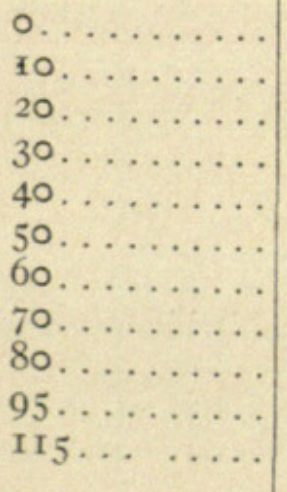 & $\begin{array}{c}\mathrm{CaCl}_{2} \\
\mathrm{NaCl} \mathrm{CaCl}_{2} \\
\mathrm{NaCl} \mathrm{CaCl}_{2} \\
\mathrm{NaCl} \mathrm{CaCl}_{2} \\
\mathrm{NaCl} \\
\mathrm{Sea} \text { water }\end{array}$ & $\begin{array}{r}\text { I010 } \\
\text { I500 } \\
880 \\
1470 \\
900 \\
1500 \\
860 \\
1470 \\
890 \\
1010 \\
1010\end{array}$ & 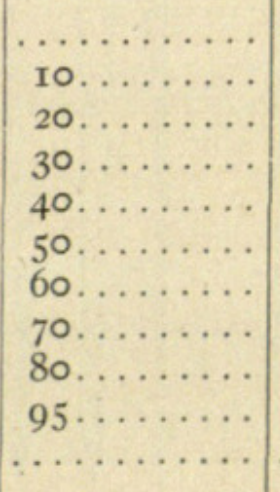 & $\begin{array}{c}\mathrm{CaCl}_{2} \\
\mathrm{NaCl}^{2} \\
\mathrm{CaCl}_{2} \\
\mathrm{NaCl} \mathrm{CaCl}_{2} \\
\mathrm{NaCl} \mathrm{CaCl}_{2} \\
\mathrm{NaCl} \\
\text { Sea water } \\
\ldots . . . . . . . .\end{array}$ & 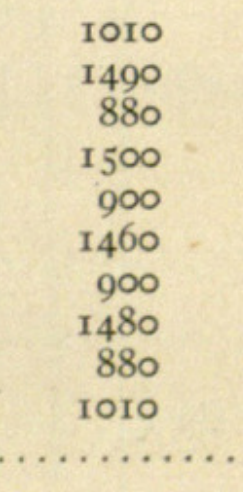 \\
\hline \multicolumn{3}{|c|}{ Control in sea water 990} & \multicolumn{3}{|c|}{ Control in sea water 990} \\
\hline
\end{tabular}

* All readings were taken at $18^{\circ} \mathrm{C}$.

The resistance of the apparatus was $240 \mathrm{ohms}$. The net resistance of the tissue at the start, therefore, was roro- $240=770 \mathrm{ohms,}$ and the net conductance $\mathrm{I} \div 770=0.00130$ mho. After the first exposure to $\mathrm{CaCl}_{2}$, the net resistance was $\mathrm{I}_{5} \mathrm{OO}-240=1260 \mathrm{ohms}$, and the net conductance was $\mathrm{I} \div \mathrm{I} 260=0.00079 \mathrm{mho}$. The loss in conductance was $0.0013-0.00079=0.0005 \mathrm{I}$ mho, or 39.2 per cent.

After the first exposure to $\mathrm{NaCl}$ the net resistance was $880-$ $240=640 \mathrm{ohms}$, and the net conductance $\mathrm{x} \div 640=0.0015^{6} \mathrm{mho}$. 
This was greater than the normal by $0.000156-0.0013=0.00026$ mho, or a gain of 20 per cent.

The fact that protoplasm is able to endure such violent alterations of permeability throws a new light on the normal life processes of the cell. In the course of metabolism a great variety of substances are produced which affect the permeability of the protoplasm. Since it is clear that the permeability may be increased or
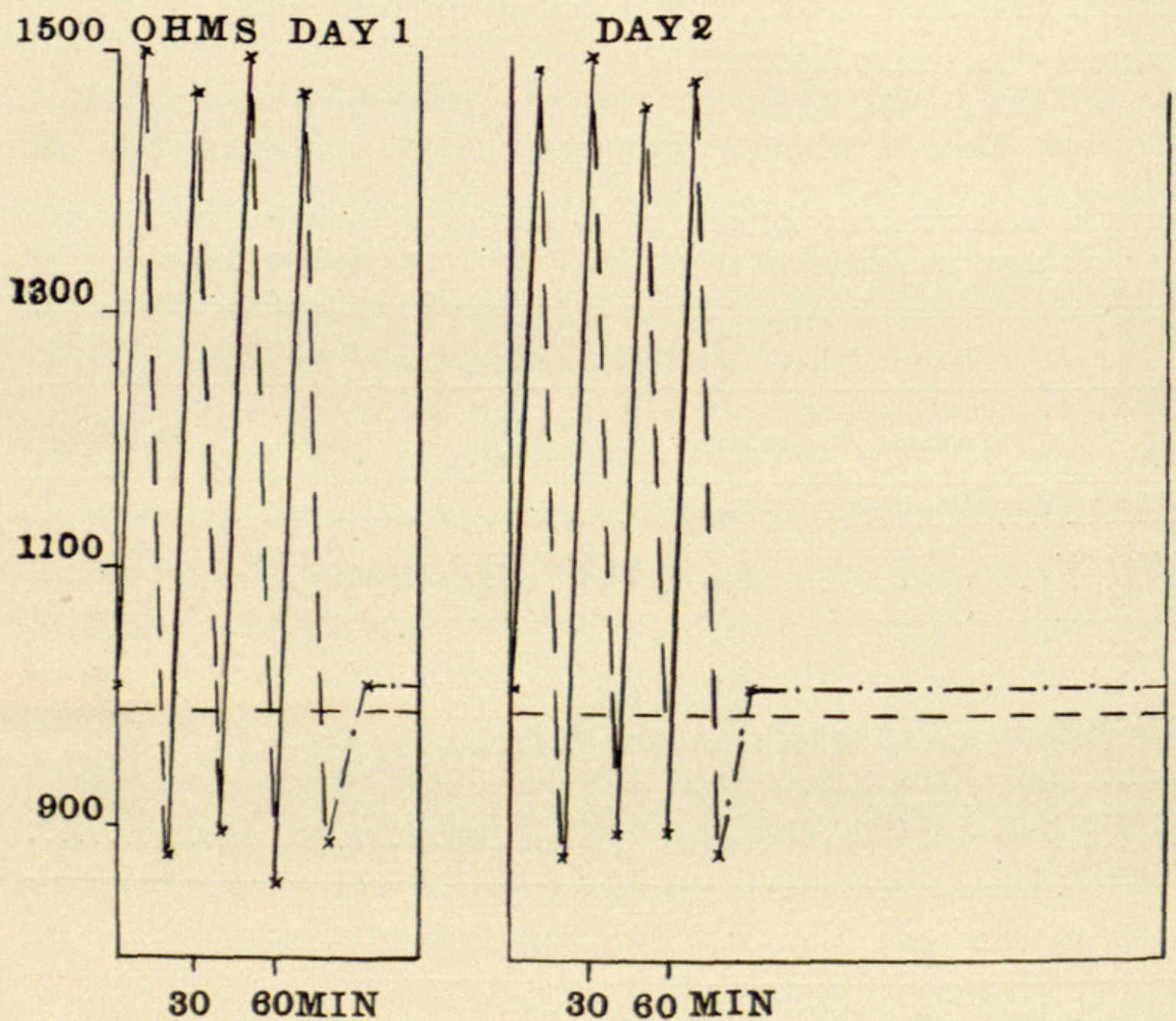

FIG. 4.-Extreme alterations of permeability shown by curves of electrical resistance of Laminaria saccharina in $\mathrm{CaCl}_{2} 0.278 \mathrm{M}$ (unbroken line), in $\mathrm{NaCl} 0.52 \mathrm{M}$ (dotted portion of curve), and in sea water (dotted line with points); horizontal dotted line, control in sea water.

decreased 30 per cent or more without rendering a return to normal permeability impossible, it is evident that considerable fluctuations in permeability may form a normal part of the life processes of the protoplasm. In this way the whole course of metabolism may be controlled, since this evidently depends on the exchange of substances between the cell and its environment. 


\section{Summary}

Results obtained by the use of quantitative methods prove that the permeability of protoplasm may be greatly increased or diminished without injury. A rapid alternation of increase (amounting to 20 per cent above normal) and decrease (amounting to 39 per cent below normal) did not produce injury.

Laboratory of Plant Physiology

HARVARD UNIVERSITY 


\section{$2 \mathrm{BHL}$ Biodiversity Heritage Library}

Osterhout, W. J. V. 1915. "Extreme Alterations of Permeability without Injury." Botanical gazette 59(3), 242-253. https://doi.org/10.1086/331528.

View This Item Online: https://www.biodiversitylibrary.org/item/109349

DOI: https://doi.org/10.1086/331528

Permalink: https://www.biodiversitylibrary.org/partpdf/223618

\section{Holding Institution}

Missouri Botanical Garden, Peter H. Raven Library

\section{Sponsored by}

Missouri Botanical Garden

\section{Copyright \& Reuse}

Copyright Status: Public domain. The BHL considers that this work is no longer under copyright protection.

This document was created from content at the Biodiversity Heritage Library, the world's largest open access digital library for biodiversity literature and archives. Visit BHL at https://www.biodiversitylibrary.org. 